\title{
Fallopian Tube Cancer pT1 TNM Finding v7
}

National Cancer Institute

\section{Source}

National Cancer Institute. Fallopian Tube Cancer pT1 TNM Finding v7. NCI Thesaurus.

Code C89670.

Fallopian tube cancer limited to fallopian tube(s). (from AJCC 7th Ed.) 